\title{
Accounting processes and their impact on the profitability of companies
}

\section{Procesos contables y su incidencia en la rentabilidad de las empresas}

QUEZADA-PACHECO, Vanessa Mariuxi†*, SOTO-AGUILAR, María Magdalena and ORELLANAULLOA, Milca Naara

Universidad Técnica de Machala, Ecuador.

ID $1^{\text {st }}$ Author: Vanessa Mariuxi, Quezada-Pacheco / ORC ID: 0000-0002-0335-8775

ID $1^{\text {st }}$ Co-author: María Magdalena, Soto-Aguilar / ORC ID: 0000-0002-8217-4922

ID $2^{\text {nd }}$ Co-author: Milca Naara, Orellana-Ulloa / ORC ID: 0000-0001-5952-5766

DOI: $10.35429 / J B S .2021 .20 .7 .1 .10$

Received July 10, 2021; Accepted December 30, 2021

\begin{abstract}
The objective of the following study is to analyze the importance of accounting processes and the impact that financial statements have on the profitability of companies through a qualitative and descriptive approach, in which it is described how important it is for companies the carrying out an efficient accounting process that leads to the correct execution of the financial statements, so that it allows the managers to make better decisions, through the different criteria of authors on the subject of study it was possible to have as the Accounting processes are of great importance for every company, since by means of the efficiency that is had, the quality of the information that will be presented in the financial statements will be given, which leaves us as a conclusion that both the accounting processes and the financial statements allow to detail the financial information that is obtained by transactional operations in this way to know in a real way the company situation
\end{abstract}

\section{Accounting processes, Financial statements, Companies}

\begin{abstract}
Resumen
El objetivo del siguiente estudio es analizar la importancia de los procesos contables y la incidencia que tienen en los estados financieros en la rentabilidad de las empresas mediante un enfoque cualitativo y descriptivo, en el que se describe cuán importante es para las empresas la realización de un eficiente proceso contable que conlleve a la correcta ejecución de los estados financieros, de modo que permita la toma de mejores decisiones a los gerentes, por medio de los diferentes criterios de autores, sobre el tema de estudio se pudo llegar a tener como los procesos contables son de gran importancia para toda empresa, ya que por medio de la eficiencia que se tenga, se dará la calidad de la información que se presentará en los estados financieros lo cual nos deja como conclusión que tanto los procesos contables como los estados financieros permitan detallar la información financiera que es obtenida por las operaciones transaccionales de esta manera conocer de forma real la situación de la empresa.
\end{abstract}

Procesos contables, Estados financieros, Empresas

Citation: QUEZADA-PACHECO, Vanessa Mariuxi, SOTO-AGUILAR, María Magdalena and ORELLANA-ULLOA, Milca Naara. Accounting processes and their impact on the profitability of companies. Journal of Business and SMEs. 2021. 7-20:1-10.

*Correspondence to the Author (Email: vquezada_est@utmachala.edu.ec)

$\dagger$ Researcher contributing first author. 


\section{Introduction}

Through this work, we will proceed to know and analyze the accounting processes that are carried out in every company, as well as the incidence that exists between the accounting processes and the financial statements.

It will be possible to know the effect that the different operations that companies carry out in adherence to accounting principles can produce.

It is mentioned that accounting information is of great importance and very useful so that the necessary decisions can be expressed and made for the good of the company; since accounting helps to make decisions, show where and how the money is spent, or what have been the commitments that have been contracted, in order to evaluate performance and give the financial implications to be able to choose the processes [1].

Financial impediments allow the prediction of future effects on decisions and know where to direct the attention that should be given to problems, imperfections and especially inefficiencies that occur today.

This research addresses an aspect that is very timely in each of the companies, it should be mentioned that in some companies the lack of clarity and the formality of the accounting that is given according to the International Financial Reporting Standards for companies.

According to IAS 1 it is indicated that the standard establishes a game full of the financial statements which are:

- Balance sheet.

- Statement of income.

- $\quad$ Statement of changes in equity

- $\quad$ Statement of cash flow and notes.

In this way, the objective of this work is to analyze the accounting processes and the impact they have on the financial statements, which will be carried out by means of a bibliographic study on the subject of study.

\section{Development}

\section{The accounting processes}

Accounting processes are considered as a variety of financial activities which begin in accordance with the transaction and end at the time the accounting books are closed, which may vary according to the cycle established for the accounting organization [2].

These works are carried out by means of an automated accounting system at the end of a cycle, which presents detailed reports. These records convey what is the real condition of the company and its purpose, from which decisions are made so that the next period is planned.

Accounting procedures are recognized as an operation that is carried out on a daily basis in the particular system of accounts, that is, it is the record of operations that are carried out in the accounting system, the same that are referred to the accounts. accounts, credits, liabilities, assets and capital, so it is a summary of the operation that occurs in debits, credits, accounts receivable and payable, the journal, account determination and finally the trial balance [3].

The information and control that is given in the accounting process establishes that an adequate measurement, management and control of the accounting processes that occur in companies be carried out through which the problems that they present, those problems that are related can be recognized with the different areas. In the same way, it allows administrators a possibility to make the best decisions in a large panorama of the information that is updated [4].

The accounting process is carried out through accounting and is carried out annually and begins on January 1 of each year, through the initial or starting situation and ends with the information given from the annual accounts that are recorded as of December 31 [5].

In the same way, it is possible to argue about the accounting processes, which are the steps, guides or instructions that are used to carry out the management and analysis of accounts that are given in the financial statements [6]. 




Figure 1 The accounting process Source: [6]

It should be mentioned that long-term income statements allow you to analyze both income and expenses and at the same time determine if these are necessary or unnecessary for the production of your company.

The accounting processes can capture, transmit and process the precise information in the decision-making process of the different users of the same [7].

The theoretical analysis refers to the accounting process as a beginning that occurs in a structure, the same that is connected by means of daily records and transactions, the same that are reflected in the accounting books of the companies.

Advantages and disadvantages of accounting processes.

Companies require control of the economic operations that are being carried out, with the sole purpose of being able to evaluate performance and present the information they generate [8].

By means of financial accounting and accounting procedures, it is determined how the basic practice that companies carry out at their different levels is carried out.

Small and medium-sized companies present the need in a smaller way than larger companies, but these present themselves in a similar way by requiring adequate and updated information to make the best decisions [9].
However, managing related processes through accounting can pose some challenges and problems, which represents a big commitment of responsibility.

Accounting processes are considered a role of great importance in companies since they allow reliable information to be obtained and in the same way it contributes to better decisions being made [10].

Next, the main advantages and disadvantages in the accounting processes of any company are presented.

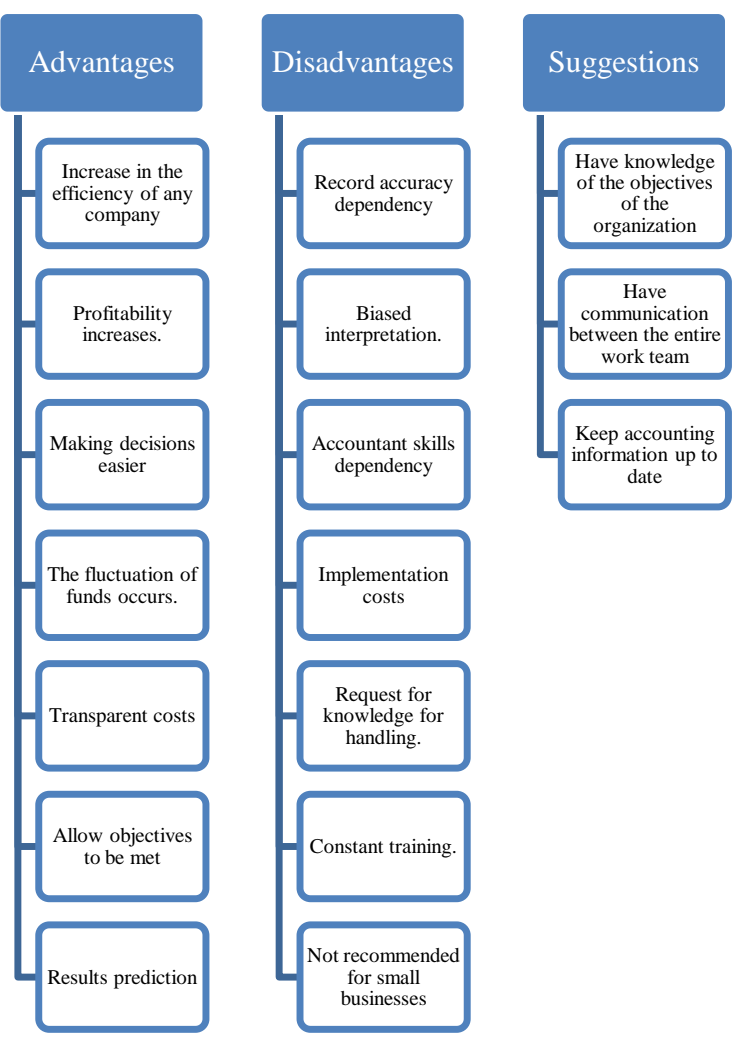

Figure 2 Advantages and disadvantages of accounting processes

Source: Own elaboration

Financial accounting procedures are used as a guarantee that some processes need so that they can be carried out in a specific way, and thus minimize the losses and mistakes. The procedures Accountants also help determine how companies can report and record financial statements [11].

Standardization is the key that allows the administration of the accounting function, ensuring that the tasks that are required are carried out and are not forgotten, the procedures also allow new personnel to be trained. 
In this way, accounting procedures are considered as a tool that provides important information on the conduct and management of the business, depending on the financial issue.

What should be made known is the importance given to the management of accounting processes and their implementation in companies or businesses, in this way the accounting information will be analyzed and interpreted in the best way.

It is necessary to consider four basic phases of the accounting process, which are:

- $\quad$ To register.

- $\quad$ Sort out.

- $\quad$ Summarize

- Interpret financial data.

In this way, the accounting information has to be communicated in an adequate way to the indicated parties after the analysis. The accounting reports have to be prepared and then distributed, for which they have to include the basic income statement and the balance sheet, in the same way they have to have additional information that allows including the accounting indices, graphs, diagrams and the flow statements. Of funds. The following image shows the processes to be followed.

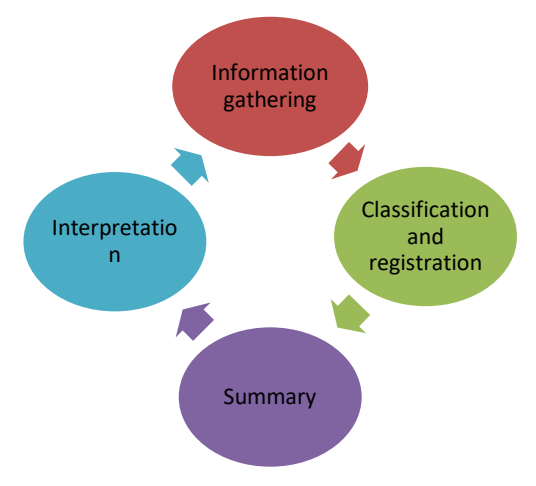

Figure 3 Phases of the accounting process Source: Own elaboration

Information Collection: this is considered a basic phase of the accounting process where transactions are recorded chronologically and systematically in the database.
The accounting records, on the other hand, are the books and documents that come to participate to make the financial statements, which include the records of the diaries, ledgers, liabilities, assets and other supporting documents such as checks and bills.

After collecting the accounting information, which is a component or element that is interrelated, so that it acts in an optimal way through an objective or the purpose they have in common, in such a way the collection of information should be reliable and safe [12].

Classification and registration: this phase groups and orders similar items under the same category, name or designated account, this phase uses a systematic analysis of the recorded data of each transaction grouping them into a single part [13].

Summary: this phase synthesizes the data, after the accounting periods, which can be monthly, quarterly, semi-annually or annually. Said data must be presented in a way that is easy to understand and can be used by external and internal users [13].

Interpretation: this phase performs an analysis of financial data, being a critical tool, which allows decision-making [13].

This final function allows the data that is recorded to be interpreted so that end users can make meaningful judgments regarding financial conditions. Additionally, it empowers the realization of plans in the future framing the policies to create financial plans that generate growth. The interpretation of the data is carried out by the accountants of each company, in order to pass detailed information to the directors of the entity, and these in turn make the correct decisions for it.

Financial Statements within the accounting process.

Financial statements provide information on performance, financial situation and changes that occur on it. The financial situation of any company is useful for the great variety of users who need it when making economic decisions, since it is oriented to detect the financial effect produced by the realization of events that occurred in the past [14]. 
The interpretation and analysis of the financial statements is given by means of a set of techniques that are applied to different statements, the same that are made by means of the accounting information that allows diagnosing the economic and financial situation of the company in order to de this way to be able to make the correct decisions and solve the weak points that have been detected [15]. The financial statements of an accounting process are the following:

\section{Balance sheet}

The balance sheet provides the general description of assets, liabilities and stockholders' equity. The date should be placed at the top of the balance sheets at the time of their preparation, which generally takes place at the end of the fiscal year [16].

The balance equation is recognized as the asset as well as the liability, such as equity or debt, these can be retained earnings and additional paid capital. Assets are listed according to balances in the order of liquidity, while liabilities are listed according to the order they are paid. Liabilities that are short-term or current are expected to be paid in the same year, while liabilities that are long-term or noncurrent (debts) will be paid after one year.

A balance sheet is recognized as a statement of the financial position that a company has where it establishes the assets, liabilities and capital in a specified time.

In other words, the balance sheet allows the net value of each business to be displayed, the company will be obliged to include the balance sheets, income statements and cash flow statements through the financial reports that are delivered to shareholders and regulatory and tax authorities. The preparation of the balance sheets is optional for sole proprietors and partnerships, but it becomes useful to be able to monitor how the company is doing.

It has not been reported on the variation over the period of time, but on the situation in a certain time, it can be understood as a photo of the financial and economic structure at a time, which is usually at the end year, which allows it to be compared with the balance sheets of other years.
Companies, as well as people in the domestic economy, present the need to be able to keep an order to organize in an efficient way what belongs to them and what they owe. For this reason, it is thanks to accounting that accounting balances are used.

When speaking of net worth, it can be calculated as an asset minus the liability, the same one that represents the contributions of both the shareholders and the owners; additionally, the results that are not distributed [17].

In the same way, when there are negative results, that is, lost, this will reduce the net worth. The net worth or stockholders' equity shows the ability of a company to be able to finance itself.

The general structure that makes up the balance sheet are assets, liabilities, and equity, the formulation is defined by a format where most of the cases obey criteria that are personal on the use of the accounts, which is why their presentation it is not standard [18]. The structure of the Balance Sheet is presented below.

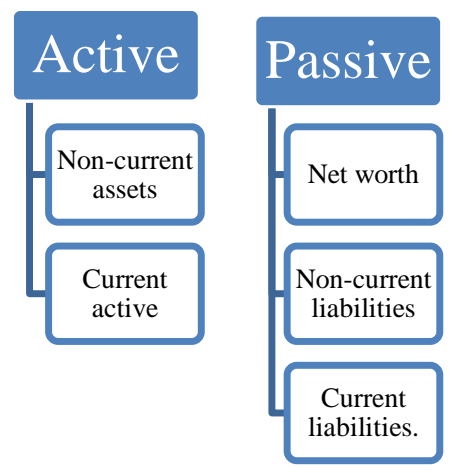

Figure 4 Balance sheet structure

Source: Own elaboration

\section{Statement of income}

The income statement, is also known by the name of income statement or profit and loss account, the same one that collects the income and expenses that the company has had in a period, through it the financial results are presented product of the actions and transactions of every company during a given period. The statement goes so far as to quantify the amounts of income that are generated and the expenses incurred, as well as the gains or losses that occur [19]. 
Through the income statement, performance is measured in a given period, it is mentioned in the accounting that the profit is reflected through income less expenses. The section of operations that is recorded by the income and expenses of a company come from operations that are main [20].

A highly important figure in the income statement is earnings before tax, which summarizes earnings before tax and financing costs.

In other parameters, the non-operating section of the income statement even includes financing costs such as expenses that are given for interest.

The income statement is known as the essential part of the financial statements, the same ones that are published in the organization, since they represent in a generalized way both the net and gross earnings of a fiscal year.

The income statement can be presented on one page or it can also be combined with comprehensive income information. In this case, the format presented in the report is called the comprehensive income statement. This is one of the five financial statements that are given in accounting [21].

\section{Income - Expenses $=$ Net Profit \\ INCOME STATEMENTS

\begin{tabular}{|l|l|}
\hline \multicolumn{1}{|c|}{ HAS TO } & TO HAVE \\
\hline SHOPPING & INCOME \\
LOSSES & LOSSES \\
EXPENSES & SALES \\
\hline
\end{tabular}

Figure 5 Profit and loss accounts Source: [21]

This indicates that the income transforms the profit according to the subtraction of the expenses, which helps to have a very quick vision of which ones are generated by the most important expenses of the company. It is in this way that, it is possible to detect where it is easier to be able to save unnecessary costs.
Thus, investors proceed to study the income statement and through analysis determine what a company is worth; on the other hand, it allows debtors to know how easy it is for companies to return the money.

\section{Cash flow statement}

The Statement of Cash Flows is the financial statement of the accounting that informs which is the origin of and how the cash is used [22].

The cash flows are presented in a format called cascade and this information is presented according to the year of its formulation and the previous one. A column is also included for cross-memory annotation.

The information contained in the cash flow statements reflects both the payments and the collections made by the company in the year, which are intended to provide great information on the collections and payments during the year.

Cash flows are the inflows and outflows of cash and other equivalent assets. They are considered cash to the treasury that is affected in the banks of entities, as well as to the bank deposits at sight. Those financial instruments that can be converted into cash are considered cash provided that the following requirements are met:

- The maturity at the time of acquisition, which should not exceed three months.

- That there is no significant risk of the variation of the value.

- They should be considered as a part of the management that is usual for the treasury.

When companies obtain money, they proceed to generate positive flows and this is achieved in three different ways:

- For customer collections (this is a business operation).

- By means of capital contributions delivered by partners, which may be through banks or creditors.

Through the sale of assets that are no longer in use. 
The statement of cash flows is calculated as follows:

\begin{tabular}{|l|l|}
\hline \multicolumn{3}{|c}{ Cash flow statement } \\
\hline$(+)$ Operations activities flow & $\$$ \\
\hline (+) Investment activities flow & $\$$ \\
\hline (+) Financing activities flow & $\$$ \\
\hline (=) Cash flow for the period & $\$$ \\
\hline Initial effective balance & $\$$ \\
\hline Initial effective balance & $\$$ \\
\hline
\end{tabular}

Figure 6 Cash flow statement

Source: Own elaboration

The following are the objectives of the statement of cash flows:

- Provide the information in a timely manner for the management, this will allow to make the decisions that allow to help the operations of their companies.

- Provide information on activities and items, where the cash has been spent.

Obtain cash flows that are passed in order to create the forecasts.

- Determine what is the capacity that companies have to be able to meet obligations with shareholders or third parties.

- It allows making decisions about the investments that will be made in the short term when there is a surplus of the cash that is available.

\section{Methodology}

The research methodology that was carried out was recognized as a specific stage of the work that was given as a part of the theoretical position and which led to the selection of techniques and methods on the procedure that is intended for the realization of the tasks that will link to the investigation [23].

This process was totally necessary in the investigation, for which reason it has been chosen to continue and be able to obtain a large amount of information that allowed us to meet the objectives set.
This type of research was carried out through a qualitative study, which required a continuous analysis of the data, which allowed it to be determined which strategies should be followed, this means what can be adapted to what it was discovered while the data was being collected.

With the above, I can describe what type of flexible designs are given for the case of analysis in companies, through an excellent design it can provide what are the necessary tools to be able to diagnose what the problem is and seek solutions according to the facts and studies.

The development of this research had a qualitative approach, the same one that I selected in order to understand what is the perspective that researchers have, through the qualitative approach it was presented to the researcher Some suggestions to be able to become familiar with the subject of the analysis of the subject, the advantages that this offers are open to information, which can be controlled in the process of expansion, which goes hand in hand in terms of the evolution of the study, a foundation is maintained that goes according to the experience and intuition that the researcher has in order to ultimately be able to guide and learn about those experiences that have been lived and about the various processes, which eventually promotes the generation of knowledge and theories to solve problems in a comprehensive way.

Another element that was used in the research that has a qualitative approach is the literary review since it allows to detect the concepts that had not been thought in the first instance, these in turn allow to nourish various ideas and various points of view according to the problem being analyzed allows us to announce which errors may be made by other researchers.

On the other hand, exploratory research is carried out when the objective consists of knowing in depth what is the nature of the phenomenon studied. 
This type of research focuses on investigating and analyzing aspects in a concrete way about reality that until now have not been analyzed in depth. In a basic way, it is an exploration that allows the investigations to be directed to the analysis of the topic in question [24].

While descriptive research selects various questions, variables, and concepts, it is It measures each of these independently for the sole purpose of being able to describe them.

Descriptive research operates at the time you want to delineate the features that are specific and discovered due to exploratory investigations. Such description is done using qualitative methods in a higher state of description [25].

Through these studies it is intended to specify which are the most important properties for people, communities, groups or other phenomenon. Through this investigation, it will be possible to know how accounting processes affect the financial statements.

\section{Results}

After analyzing the research topic, it can be had as a result that accounting processes are of great importance for every company, since through the efficiency that is had, the quality of the information that will be presented in the financial statements will be given, which, because of business management, are prepared, presented and shown schematically through equity and movement accounts.

It can be noted that the incidence of accounting processes in the financial statements is of great importance, and that these allow an overview of the results to be obtained, analyzing and comparing the data from previous periods.

\section{Conclusions}

The accounting processes are carried out with the sole purpose of being able to record those economic transactions in a specific period, through the accounting books which can be both physical and electronic
Financial statements provide useful and understandable information for companies, these are recognized as accounting reports, which allow to detail the financial information that is obtained by transactional operations and allow to know in a real way the situation of the company, thus demonstrating the reasonableness of the results at the end of a financial year.

\section{References}

1 Navarro, O., Lopez, M., \& Perez, M. (2017). Normas de control contable: operación imprescindible en la gestión empresarial: un caso ecuatoriano. Revista Universidad y Sociedad, 9(2), 46-51. http://scielo.sld.cu/pdf/rus/v9n3/rus0731 7.pdf

2 Guillen, F., \& Zambrano, N. (2018). La contabilidad y el procesamiento de la información contable. ARJÉ. Revista de Postgrado, 12(22), 307-315. http://arje.bc.uc.edu.ve/arje22/art40.pdf

3 Elizalde, K. (2019). El proceso contable según las normas internacionales de información financiera. Ciencia Digital, $3(3)$,

254-273. doi:https://doi.org/10.33262/cienciadigit al.v3i3.3.813

4 Uribe, R. (2016). La información y el control en el proceso contable. COntaduría Universidad de Antioquia., 49(1), $\quad 159 \quad$ - $\quad 171$. https://aprendeenlinea.udea.edu.co/revist as/index.php/cont/article/download/2565 $7 / 21180$

5 Hurtado, E., \& Hernandez, L. (2017). "Procesos contables y su incidencia en la razonabilidad de los Estados Financieros. Revista Observatorio de la Economía, 1-5. https://www.eumed.net/cursecon/ecolat/ ec/2017/procesos-contables.html 
Santos, C. (2017). Diseño e implementación del procedimiento contable en la Organización Nacional de Bufetes Colectivos. Cofín Habana(11), 153-166.

http://scielo.sld.cu/scielo.php?script=sci _arttext\&pid=S2073-

60612017000200011

7 García, A. (2019). Los procesos contables de la auditoria en una gestión empresarial. FIPCAEC, 4(4), 3-14. . https://fipcaec.com/index.php/fipcaec/ar ticle/view/34/33

8 Morales, L., Sanchez, A., \& Viscaino, C. (2019). Importancia de los fundamentos contables. Aplicación práctica de un proceso contable en una empresa comercial. revista de investigación sigma, 6(1), 84-100. . https://webcache.googleusercontent.com /search?q=cache:NSqvlFyZMOwJ:https ://journal.espe.edu.ec/ojs/index.php/Sig $\mathrm{ma} /$ article/download/1233/961+\&cd=13 $\& \mathrm{hl}=\mathrm{es} \& \mathrm{ct}=\mathrm{clnk} \& \mathrm{gl}=\mathrm{ec} \& \mathrm{client}=$ firefox $-b-d$

9 Carranza, G., \& Cedño, P. (2020). Proceso contable para mejorar la presentación de los. Revista Científica Arbitrada, 3(6), 10-17.

https://publicacionescd.uleam.edu.ec/ind ex.php/corporatum-

360/article/view/103/210

Rodriguez, A., Velastegui, L., \& Maldonado, H. (2019). Proceso contable: herramienta financiera para la toma de decisi. Revista Dilemas Contemporáneos: Educación, Política y Valores.(42), 1-22.

https://www.dilemascontemporaneosedu cacionpoliticayvalores.com/index.php/di lemas/article/view/1397/1689

11 Crespo, J., Carchi, K., \& Zambrano, A. (2020). Mejora Continua en el proceso contable y su aporte en la competitividad de las MIPYMES en la Provincia de El Oro (Ecuador). Espacios, 41(1), 1-11. . http://www.revistaespacios.com/a20v41 n01/a20v41n01p03.pdf
12 Torres, A. (2020). Elementos de un sistema de información contable efectivo. QUIPUKAMAYOC, 27(53), 73-79. doi:http://dx.doi.org/ 10.15381/quipu.v27i53.15988

13 Fernandez, A. (2018). Fases de los procesos contables. https://www.cuidatudinero.com/130923 06/cuales-son-las-fases-basicas-de-lacontabilidad

14 Saenz, L. (2020). Estados financieros: competenciacontable básica en la formación decontadores públicos autorizados. Revista Saberes APUDEP, 3(2), 1-8. http://portal.amelica.org/ameli/jatsRepo/ 223/2231336006/2231336006.pdf

15 Mustelier, M., Díaz, Y., \& León, A. (2018). metodología para el análisis financiero en la actividad presupuestada. Universidad\&Ciencia, 7(2), 169-181. . https://core.ac.uk/download/pdf/287219 383.pdf

16 Barreto, N. (2020). Análisis financiero: factor sustancial para la toma de decisiones en una empresa del sector comercial. Universidad y Sociedad, 12(3), 129-134.

http://scielo.sld.cu/pdf/rus/v12n3/22183620-rus-12-03-129.pdf

17 Velez, D., \& Duque, V. (2017). "La Contabilidad del Patrimonio y su presentación en el Estado de Situación Financiera de la Comercializadora Aluminios Ecuatorianos ALUMEC ATCI S.A". Revista Observatorio de la Economía Latinoamericana,, 1-17. . https://www.eumed.net/cursecon/ecolat/ ec/2017/comercializadoraalumecatcisa.html

18 Elizalde, L. (2019). Los estados financieros y las políticas contables. 593 Digital Publisher, 4(5), 217-226. doi:https://doi.org/10.33386/593dp.2019 .5-1.159 
19 Puerta, F., Vergara, J., \& Huertas, N. (2018). Análisis financiero: enfoques en su evolución. Calidad Academica, $16(28)$, 85-104.

https://webcache.googleusercontent.com /search?q=cache:k0qj0W5Itq0J:https://d ialnet.unirioja.es/descarga/articulo/6676 021.pdf $+\& \mathrm{~cd}=12 \& \mathrm{hl}=\mathrm{es} \& \mathrm{ct}=\mathrm{clnk} \& \mathrm{gl}=\mathrm{e}$ $c \&$ client=firefox-b-d

20 Muñoz, J. (2018). Análisis a los estados financieros de empresas camaroneras en la provincia. INNOVA, 3(9), 102-115. . https://revistas.uide.edu.ec/index.php/in nova/article/view/686/1177

21 Guadalupe, C. (2019). "estado de resultados integrales dispuestos en las NIIF". Observatorio de la Economía Latinoamericana, $\quad$ 1-10.

https://www.hacienda.go.cr/Sidovih/upl oads/Archivos/Articulo/Estado\%20de\% 20resultados\%20integrales\%20dispuest os\%20en\%20las\%20NIIF-

Revista\%20Observatorio\%20de\%201a\% 20Econom\%C3\%ADa\%20Latinoameric ana-febrero\%202019.pdf

22 Barbosa, D., \& Villazana, J. (2018). Como elaborar un estado de flujo de efectivo por el método directo. Revista GEON, 5(1), 6-14. doi:https://doi.org/10.22579/23463910.3 5

23 Viñan, J., \& Navarrete, F. (2018). Metodología de la investigación científica como instrumento en la producción y realización de una investigación. Revista Atlante: Cuadernos de Educación, 1-10. . https://www.eumed.net/rev/atlante/2018 /05/investigacion-cientifica.html

24 Castro, A., \& Melendez, L. (2018). La investigación exploratoria aplicada como estrategia didáctica en el laboratorio. Revista Electrónica sobre Cuerpos Académicos y Grupos de Investigación, 5(10), 1-9. . http://webcache.googleusercontent.com/ search?q=cache:vJRloCk7lAQJ:www.c agi.org.mx/index.php/CAGI/article/dow nload/184/364/909+\&cd=11\&hl=es\&ct $=c \operatorname{lnk} \& \mathrm{gl}=\mathrm{ec} \& \mathrm{client}=$ firefox $-\mathrm{b}-\mathrm{d}$
Díaz, V., \& Calsadilla, A. (2016). Artículos científicos, tipos de investigación y productividad científica en las Ciencias de laSalud. Revista Ciencias de la Salud, 14(1), 115-121. . https://www.redalyc.org/pdf/562/56243 931011.pdf. 